\title{
Aqueous dispersions of epoxy oligomers: Stability and rheological properties
}

D. A. Busel ${ }^{1}$,

V. D. Koshevar',

A. Zarkov²,

\section{G. Shkadrecova ${ }^{1}$,}

\author{
A. Kareiva ${ }^{2^{*}}$ \\ ${ }^{1}$ Institute of General and \\ Inorganic Chemistry, \\ The National Academy of Sciences \\ of Belarus, \\ 9/1 Surganov Street, \\ BY-220072 Minsk, Belarus \\ ${ }^{2}$ Institute of Chemistry, \\ Vilnius University, \\ 24 Naugarduko Street, \\ 03225 Vilnius, Lithuania
}

In this study, the stability of the aqueous dispersions of epoxy oligomers was investigated. The following epoxy oligomers with various numbers of epoxy groups were used for the characterization: NPEL 127, NPEL 128, NPEL 134, NPPN 631, EPOXY 520 and DEG-1. A non-ionic surfactant Emulsogen LCN-287 based on alkyl polyethylene glycol ether was used as an emulsifier. The dispersions of epoxy resins were fabricated by changing the content of a non-ionic surfactant (emulsifier) in a range from 2 to $6 \mathrm{wt} . \%$. It was demonstrated that the stability of aqueous emulsions depends not only on the type of resin, but also on the content of the oil phase and the concentration of the emulsifier. The rheological properties of the aqueous dispersions of epoxy oligomers were investigated as well.

Keywords: epoxy oligomers, aqueous dispersions, stability, rheological properties

\section{INTRODUCTION}

Aqueous dispersions (emulsions) of epoxy resins are widely used as thin/thick films for the production of paints and varnishes, as anticorrosion coatings and in the building materials industry [1-5]. This is due to both their high environmental safety compared to those of organic-soluble analogues, and the need to create water-based decorative and protective compositions of a higher quality than those obtained on the basis of synthetic latexes [691. A significant number of available publications devoted to aqueous dispersions of epoxy resins are predominantly related with fabrication of multifunctional composites [10-15.

The effects of ultrasonication on the epoxy resin and its emulsion were investigated to find out its

\footnotetext{
* Corresponding author. Email: aivaras.kareiva@chgf.vu.lt
}

room temperature storage stability and centrifugal stability [16]. It was determined that the molecular weight of the epoxy resin was initially decreased and then stabilized by the increasing of ultrasonic irradiation time. Shi et al. [17] successfully synthesized waterborne difunctional polyacrylate with long fluorinated side chains and epoxy groups which was used as an emulsifier and reactive surface modifier for epoxy resin. It was also demonstrated that waterborne epoxy emulsified asphalts have high densities, good chemical stabilities and high viscosities. Besides, waterborne epoxy dispersions have an excellent permeability and adhesion to various polar substrates and they are widely used as coatings and adhesives in industrial applications [18, 19].

The rheological behaviour of the aqueous emulsions of epoxy resins is also a very important technological parameter. It was proved in several recent works [20-22]. It was demonstrated 
that the introduction of polybenzoxazine into the epoxy network improved the thermomechanical properties of neat epoxy resins. These results also revealed that differently modified asphalt emulsions gave better performance as compared with that of unmodified emulsion. Until now, however, there is no clear idea of the effect of the chemical nature of resins on their ability to emulsify in water with the formation of sufficiently stable technological dispersions. There are no systematic studies of the influence of various factors on the colloidal-chemical properties of emulsions of these resins. In this regard, in this work, the aim was to study the effect of the chemical nature of epoxy oligomers, the quantitative ratio of phases, the concentration of the emulsifier on the stability and rheological behaviour of their aqueous dispersions.

\section{EXPERIMENTAL}

In the study, the following epoxy oligomers (EO) with various numbers of epoxy groups were used: NPEL 127, NPEL 128, NPEL 134, NPPN 631 (Nan Ya Corporation, Taiwan), EPOXY 520 (Heureka, Czeck Republik) and DEG-1 (Russia). Table 1 shows the main physical and chemical properties of investigated resins. These selected epoxy resins contain different chemical structures depending on the method of their preparation. The chemical structures of NPEL 127, NPEL 128 and NPEL 134 are presented in Fig. 1, and the structures of NPPN 631, EPOXY 520 and DEG-1 are shown in Fig. 2. A non-ionic surfactant Emulsogen LCN287 (Clariant, Germany) based on alkyl polyethylene glycol ether was used as an emulsifier. The surface tension of surfactant was $38.72 \mathrm{mN} / \mathrm{m}$.

The dispersions of epoxy resins were fabricated by changing the content of a non-ionic surfactant (emulsifier) in a range from 2 to $6 \mathrm{wt} . \%$. The phase ratio of resin:water was the following: 1:9, 1:4, 1:1, $3: 2$ and 3:1. For the emulsification of the resins, initially a solution of the emulsifier in water was prepared. Then, the calculated amount of resin was gradually introduced into the resulting solution and the contents were subjected to dispersion on a laboratory dispersing device LDU-3 MPR (RF) at a rotor speed of $5000 \mathrm{rpm}$ (average speed of rotation $85 \pm 5 \mathrm{~s}^{-1}$ ). The dispersion time established in preliminary experiments was 10 min in all cases. At the end of the dispersion process, the resulting dispersion was placed in cylinders $(25 \mathrm{ml})$ and the appearance and movement of the interface were monitored.

The surface tension of the resins and surfactant was determined by the plate tearing method (Wilhelmy method) under isothermal conditions at $20 \pm 0.5^{\circ} \mathrm{C}$. The studies were carried out using an automatic device Tensiometer K-100 MK 2 (KRUSS, Germany). The parameters were calculated using the LabDeskTM software. When determining the surface tension, the correction

Table 1. Physicochemical characteristics of resin samples

\begin{tabular}{ccc|c|c}
\hline Resin & Molar mass, $\mathbf{g} / \mathbf{m o l}$ & $\begin{array}{c}\text { Mass fraction of epoxy } \\
\text { groups, } \%\end{array}$ & Surface tension, $\mathbf{m N} / \mathbf{m}$ & Density, $\mathbf{g} / \mathbf{c m}^{\mathbf{3}}$ \\
\hline DEG-1 & 167.3 & 25.70 & 38.6 & 1.177 \\
\hline NPPN 631 & 174.0 & 24.71 & 50.0 & 1.210 \\
\hline NPEL 127 & 183.9 & 23.38 & 46.4 & 1.167 \\
\hline NPEL 128 & 186.5 & 23.06 & 46.5 & 1.169 \\
\hline EPOXY 520 & 190.5 & 22.41 & 47.0 & - \\
\hline NPEL 134 & 242.8 & 17.71 & - & - \\
\hline
\end{tabular}<smiles>CC(C)(COc1ccc(C(C)(C)c2ccc(OCC(O)CC3CCCO3)cc2)cc1)c1ccc(OCC2CO2)cc1</smiles>

Fig. 1. The schematic of chemical structures of NPEL 127, NPEL 128 and NPEL 134 resins 


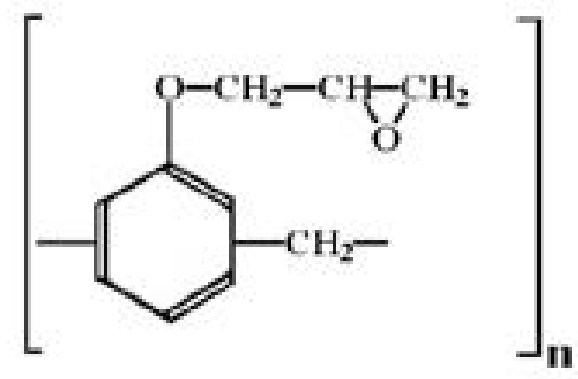

Fig. 2. The schematic of chemical structures of NPPN 631 (top) and EPOXY 520 and DEG-1 (bottom) resins

factors from the tables of Harkins and Jordan were used. The granulometric composition of the emulsion during storage was investigated on an FSKh-4 automatic photo sedimentometer, which made it possible to judge their aggregate stability by changing the content of individual fractions of drops.

Rheological studies were carried out at $20^{\circ} \mathrm{C}$ using a Physica MCR 101 automatic rheometer on air bearings (Munzing Chemie, Austria) with a Rheoplus computer control program (the shear strain rate in a stationary mode varied from 1 to $300 \mathrm{~s}^{-1}$ ). A 'plate-plate' system with a gap of $0.5 \mathrm{~mm}$ was used as a measuring system.

\section{RESULTS AND DISCUSSION}

The specimen EPOXY 520 has been selected as the representative sample for the investigation of influence of the emulsification method on the stability of the aqueous dispersion of epoxy oligomer. Figure 3 shows the dependence of the stability of EPOXY 520 dispersions obtained by direct dispersion on the concentration of surfactant. The use

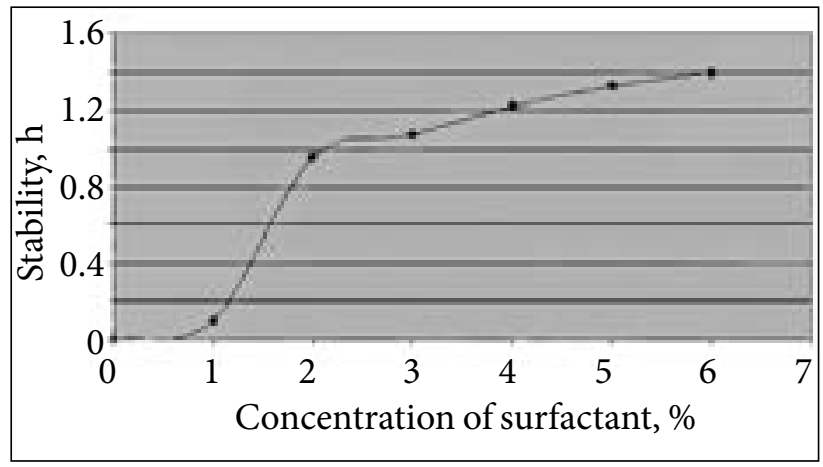

Fig. 3. The dependence of the stability of EPOXY 520 dispersions obtained by direct dispersion on the concentration of surfactant of the direct dispersion method does not provide a high dispersion stability for Epoxy 520. As seen, the maximum stability time is $1.4 \mathrm{~h}$ with an emulsifier content of more than $6 \mathrm{wt} . \%$. When resin was dispersed without an emulsifier and with an amount of less than $1 \%$, the instantaneous separation of the system occurs.

The results of the stability of dispersion obtained using the reverse dispersion method are depicted in Fig. 4 Evidently, the dispersion performed by the reverse method is more effective than the direct one. As seen from Figs 3 and 4 the aggregate stability of the dispersion increased significantly (by two orders of magnitude). It can also be concluded that the optimal content of surfactant in the system is about 4 mass.\% for this case. If the surfactant concentration is less than $4 \%$, it is likely that sufficiently adsorptionsaturated and mechanically strong adsorption layers were not formed, which leads to the coalescence of drops and the separation of the system into two phases. It was also determined that the temperature affected the stability of the dispersion significantly. With increasing the temperature above $50^{\circ} \mathrm{C}$ the decreasing in aggregate stability was observed. Moreover, the complete stratification of the system occurred within $6 \mathrm{~h}$ at $70^{\circ} \mathrm{C}$.

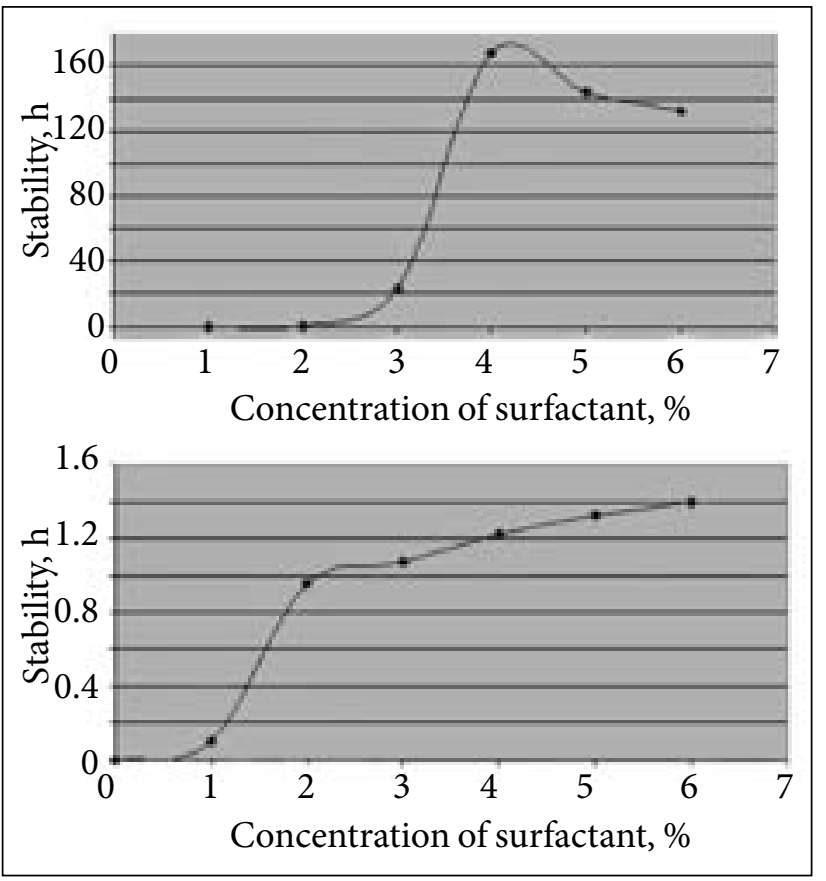

Fig. 4. The dependence of the stability of EPOXY 520 dispersions obtained by reverse dispersion on the concentration of surfactant 
Table 2. Stability of epoxy resin dispersions

\begin{tabular}{|c|c|c|c|c|c|c|}
\hline \multirow{2}{*}{ Resin } & \multirow{2}{*}{$\begin{array}{l}\text { Concentration of } \\
\text { surfactant, } \%\end{array}$} & \multicolumn{5}{|c|}{ Stability depending on the ratio of resin:water, $h$} \\
\hline & & 3:1 & $3: 2$ & 1:1 & $1: 4$ & 1:9 \\
\hline \multirow{3}{*}{ DEG-1 } & 2 & 744 & 744 & 0.5 & 0.5 & 744 \\
\hline & 4 & 744 & 744 & 0.5 & 24 & 24 \\
\hline & 6 & 744 & 744 & 24 & 24 & 744 \\
\hline \multirow{3}{*}{ NPEL 128} & 2 & 282 & 282 & 282 & 282 & 0.3 \\
\hline & 4 & 600 & 600 & 600 & 67 & 67 \\
\hline & 6 & 556 & 556 & 556 & 4.2 & 0.3 \\
\hline \multirow{3}{*}{ NPEL 127} & 2 & 744 & 528 & 528 & 341 & 144 \\
\hline & 4 & 744 & 744 & 744 & 1.6 & 1.3 \\
\hline & 6 & 744 & 744 & 744 & 22 & 19 \\
\hline \multirow{3}{*}{ NPPN 631} & 2 & 472 & 216 & 217 & 143 & 195 \\
\hline & 4 & 671 & 259 & 288 & 336 & 119 \\
\hline & 6 & 744 & 217 & 217 & 139 & 139 \\
\hline
\end{tabular}

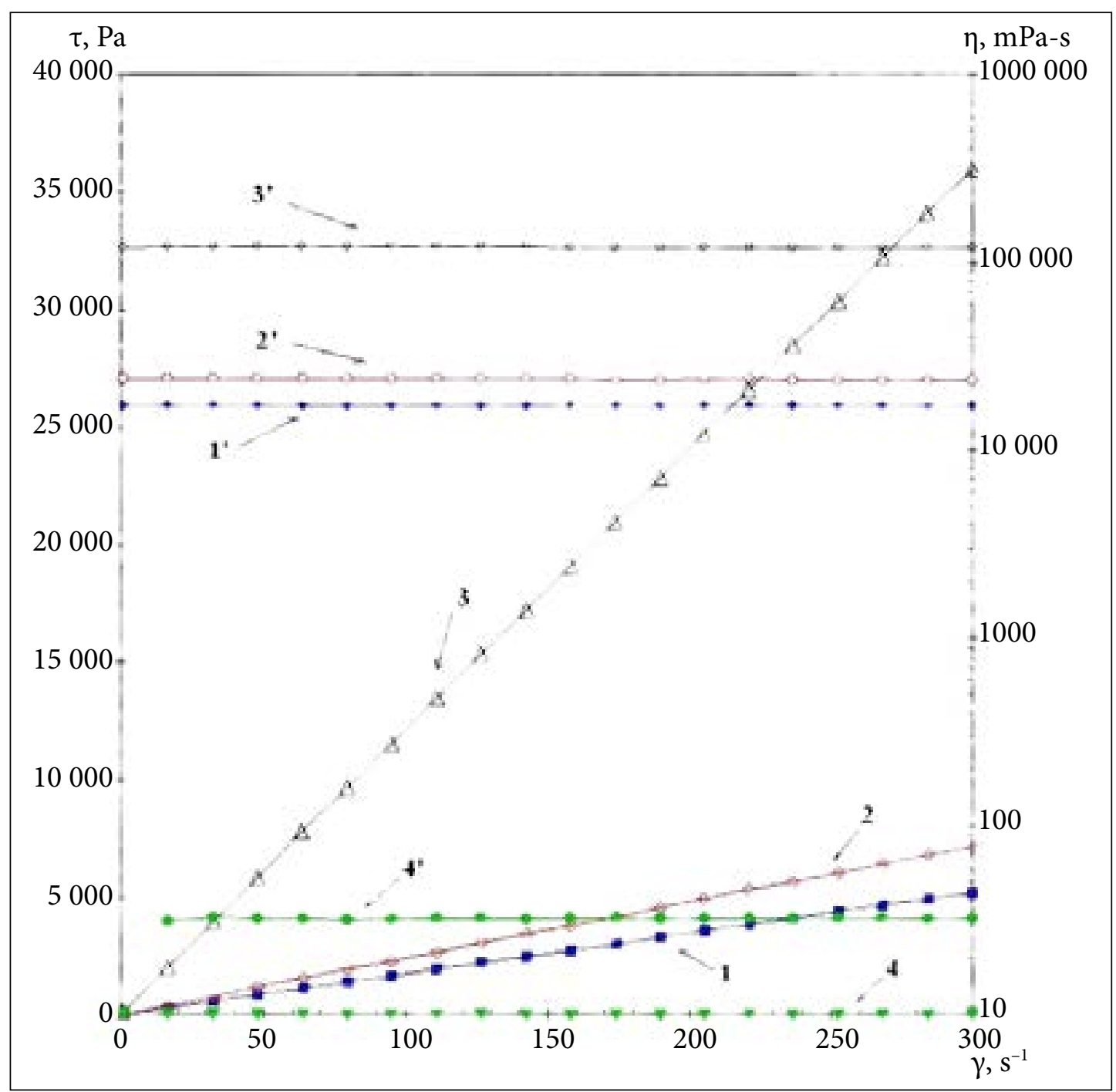

Fig. 5. Shear stress and dynamic viscosity versus shear rate for NPEL $127\left(1,1^{\prime}\right)$, NPEL $128\left(2,2^{\prime}\right), \operatorname{NPPN} 631\left(3,3^{\prime}\right)$ and DEG 1 $\left(4,4^{\prime}\right)$ resins. (1-4) shear stress and $\left(1^{\prime}-4^{\prime}\right)$ viscosity 
Table 2 shows the stability data of emulsions of different resins. From the results summarized in Table 2 it can be concluded that the stability of aqueous emulsions depends not only on the type of resin, but also on the content of the oil phase and the concentration of the emulsifier. For the NPEL 128 and NPEL 127 resins, the emulsion resistance to delamination increases, peaking at a 1:1 ratio and maintaining it at 3:2 and 3:1 ratios. For the NPPN 631 resin, the emulsion resistance to delamination increases, reaching a maximum at an oil phase content of $3: 1$ and an emulsifier content of $6 \%$. The DEG-1 resin has the best stability indicators for emulsions, however, this resin is not used in its pure form for the fabrication of coatings. Therefore, of the above resins, NPEL 127 is the most promising for further research. The greatest stability of dispersions of this resin is observed in a fairly wide range of emulsifier content $2-6 \%$ by weight, also with a resin:water phase ratio from 1:1 to 3:1. The concentration of the emulsifier in the solution is 4.5 times higher than the critical micelle concentration (CMC).

Figure 5 shows the rheological curves of individual EOs. It can be seen that they behave like Newtonian fluids, since during their flow the viscosity $(\eta)$ remains constant at various shear rates $(\gamma)$, and a linear dependence of the shear stress $(\tau)$ on the value of $\gamma$ was observed. The highest viscosity is possessed by the resin NPPN 631. On the other hand, the resin DEG-1 shows the least viscosity.

\section{CONCLUSIONS}

It was demonstrated that the use of the direct dispersion method did not provide a high dispersion stability for epoxy resins. On the contrary, the dispersions performed by the reverse method were more effective than the direct one. It was also determined that the stability of the dispersions was dependent on the temperature. With increasing the temperature above $50^{\circ} \mathrm{C}$ the decreasing in aggregate stability was observed. Moreover, the complete stratification of the system occurred within $6 \mathrm{~h}$ at $70^{\circ} \mathrm{C}$. It can also be concluded that the stability of aqueous emulsions depended not only on the type of resin, but also on the content of the oil phase and the concentration of the emulsifier. For the NPEL 128 and NPEL 127 resins, the emulsion resistance to delamination increased, peaking at a 1:1 ratio and maintaining it at 3:2 and 3:1 ratios. For the NPPN 631 resin, the emulsion resistance to delamination increased, reaching a maximum at an oil phase content of $3: 1$ and an emulsifier content of $6 \%$. The NPPN 631 resin showed the highest viscosity, while the resin DEG-1 showed the lowest viscosity.

Received 2 August 2021 Accepted 16 August 2021

\section{References}

1. K. Hibino, Y. Kimura, Macromolec. Mater. Eng., 286, 325 (2001).

2. Y. F. Li, L. Yang, X. H. Gao, et al., New Mater. Adv. Mater., Adv. Mater. Res., 152-153, 1890 (2011).

3. O. Niculescu, Z. Moldovan, M. Leca, et al., J. Polym. Eng., 35, 463 (2015).

4. N. Ning, W. S. Liu, Q. L. Hu, et al., Compos. Sci. Technol., 199, 108364 (2020).

5. F. Yu, H. Y. Feng, L. H. Xiao, et al., Progr. Org. Coat., 155, 106221 (2021).

6. J. Kozakiewicz, I. Ofat, J. Trzaskowska, et al., Progr. Org. Coat., 78, 419 (2015).

7. J. Sun, H. G. Fang, H. L. Wang, et al., J. Polym. Eng., 7, 113 (2017).

8. J. Y. Jung, J. H. Lee, C. G. Park, J. Appl. Polym. Sci., 127, 3522 (2013).

9. M. L. Vo, J. Plank, Constr. Build. Mater., 169, 93 (2018).

10. D. Vennerberg, Z. Rueger, M. R. Kessler, Polymer, 55, 1854 (2014).

11. K. X. Pan, X. R. Zeng, H. Q. Li, et al., J. Adhes. Sci. Technol., 30, 1131 (2016).

12. M. A. De Farias, L. A. Coelho, S. H. Pezzin, Mater. Res. Ibero Am. J., 18, 1304 (2015).

13. M. A. De Farias, S. C. Amico, L. A. Coelho, et al., Polym. Plast. Technol. Mater, 59, 517 (2020).

14. Y. K. Xie, W. Q. Liu, L. Y. Liang, et al., J. Appl. Polym. Sci., 137, e49405 (2020).

15. Y. D. Meng, G. D. Sun, Y. Huang, et al., Macromolec. Mater. Eng., 305, 2000178 (2020).

16. L. Z. Liu, G. K. Hu, X. R. Zhang, et al., Pigm. Resin Technol., 47, 300 (2018).

17. H. Y. Shi, S. He, W. Q. Liu, et al., J. Coat. Technol. Res., 17, 427 (2020).

18. X. Cai, W. K. Huang, J. Liang, et al., Front. Mater., 7, 88 (2020).

19. D. Ai, R. B. Mo, H. H. Wang, et al., Progr. Org. Coat., 136, 105258 (2019).

20. R. Ambrozic, U. Sebenik, M. Krajnc, Eur. Polym. J., 81, 138 (2016).

21. A. M. M. Abd El-Rahman, M. El-Shafie, Z. L. AboShanab, et al., Petrol. Sci. Technol., 35, 1473 (2017).

22. J. S. Li, Z. Zhu, L. Ke, et al., Road Mater. Pavement, Early Access (2020). 
D. A. Busel, V. D. Koshevar, A. Žarkov,

V. G. Shkadrecova, A. Kareiva

VANDENINĖS EPOKSIDINIỤ OLIGOMERŲ

DISPERSIJOS: STABILUMAS IR REOLOGINĖS

SAVYBĖS

Santrauka

Šiame darbe pirmą kartą buvo tirta epoksidinių oligomerų vandeninių dispersijų stabilumas. Apibūdinimui buvo naudojami šie epoksidiniai oligomerai, pasižymintys ịvairiu epoksidinių grupių skaičiumi: NPEL 127, NPEL 128, NPEL 134, NPPN 631, EPOXY 520 ir DEG-1. Kaip emulsiklis buvo naudojamas nejoninis paviršinio aktyvumo agentas alkilpolietilenglikolio eterio pagrindu „Emulsogen LCN-287“. Epoksidinių dervų dispersijos buvo pagamintos keičiant nejoninès paviršinio aktyvumo medžiagos (emulsiklio) kiekị nuo 2 iki $6 \%$. Irodyta, kad vandeninių emulsijų stabilumas priklauso ne tik nuo dervos tipo, bet ir nuo aliejinès fazès kiekio bei emulsiklio koncentracijos. Taip pat buvo tiriamos epoksidinių oligomerų vandeninių dispersijų reologinès savybès. 